\title{
INTERNATIONAL UNION OF GEODESY AND GEOPHYSICS
}

\author{
ROME ASSEMBLY, I 954

\section{MEETING OF THE COMMISSION ON SNOW AND ICE}

THE next general assembly of the I.U.G.G. will take place in Rome in the latter half of September 1954, when the Commission on Snow and Ice of the International Association of Hydrology wil hold its meetings.

It will be of interest to members of the British Glaciological Society to note that, as stated in the report of the meeting of the Commission at Brussels in $195 \mathbf{I}$, (Fournal of Glaciology, Vol. 2, No. II, March 1952, p. 60), no subjects have been set for papers to be read in 1954, in order to leave wider latitude to research workers.

Members will be pleased to note that Mr. G. Seligman and Professor R. Haefeli are respectively President and Vice-President of the Commission, and its Honorary Secretary is Mr. P. D. Baird, 3485 University Street, Montreal, Canada.

The Corresponding Member of the British Group of members of the Commision is Professor Gordon Manley, Bedford College, Regent's Park, London, N.W.2.

The names of British members of the Commission, and of British delegates to the meeting, will be announced later.

V. E. Fuchs

\section{GLA C I O L O G I C A L L I T E R A T U R E}

THIs bi-annual list of glaciological literature aims to cover the scientific aspects of snow and ice in all parts of the world. Attention is drawn to the bibliographies in each number of the Polar Record (Cambridge), which aim to cover the significant work dealing with expeditions, research, equipment and conditions of living in the Polar regions. Both journals, however, deal with Polar literature having specific glaciological interest and with general matters of a practical
nature such as snowcraft.

Readers will greatly assist the Editor by notifying him of their own, or any other, publication of glaciological interest.

Aliverti, G. Sopra i fenomeni di ablazione e di movimento sulla lingua del ghiacciaio del Lys. Bollettino del Comitato Glaciologico Italiano, 2 Ser., No. 3, 1952 , p. $17-23$.

Allison, IrA S. Dating of pluviai lakes in the Great Basin. American fournal of Science, Vol. 250, No. 12, 1952, p. $907-09$. 1951-52. Bollettino del Comitato Glaciologico Italiano, 2 Ser., No. 3, 1952, p. 195-271. [Snow cover in various
districts in Italy.]

Antevs, ERnst. Geochronology of the Deglacial and Neothermal Ages. Fournal of Geology, Vol. 61, No. 3, 1953, p. $195^{-230}$.

ARNBERGER, E. roo Jahre Veränderungen des Goldberg Gletschers in der Sonnblickgruppe. Mitteilungen der Geographischen Gesellschaft Wien, Bd. 94, Ht. 5/8, 1952, p. $270-74$. [Area $2 \cdot 7 \mathrm{~km}^{2}{ }^{2}$ in 1850 and $\mathrm{I}^{\cdot} 75 \mathrm{~km}^{2}$ in 1950. .]

Ashmore, S. E. Records of snowfall in Britain. Quarterly Fournal of the Royal Meteorological Society, Vol. 78 , No. 338 , 1952, p. $629-32$. [Equations given for correcting less accurate records.]

BAIRD, P. D. Baffin Expedition 1950. Canadian Geographical fournal, Vol. 42, No. 5, 1951, p. 2 I $2-23$.

BAtTLE, W. R. B. Contributions to the glaciology of north-east Greenland, $1948-49$, in Tyrolerdal and on Clavering $\varnothing$. Meddelelser om Grønland, Bd. 136 , Nr. 2, 1952 , [second article] 28 p.

BAUER, A. Wissenschaftliche Ergebnisse der französischen Polarexpeditionen. Naturwissenschaftliche Rundschau, Jahrg. 5, Ht. I, 1952, p. I-8; Ht. 2, 1952, p. 49-54.

BAY, C. E., and others. Frost penetration into soils as influenced by depth of snow, vegetative cover, and air temperatures. By C. E. Bay, G. W. Wunnecke and O. E. Hays. Transactions. American Geophysical Union, Vol. 33, No. 4, 1952,
p. 54I-46. BIRD, J. BRIAN. The glaciation of central Keewatin, Northwest Territories, Canada. American fournal of Science, Vol.
25I, No. 3, I953, p. 215-30.

Blache, Jules. La sculpture glaciaire. Revue de Géographie Alpine, Tom. 40, Fasc. I, 1952, p. 31-123. [Emphasis on

the efficacy of the great glaciations and on the part played by the speed of movement of glaciers.]
Bowen, W. A., jr. RCA electronic ice gage- evaluation under Arctic conditions. U.S. Naval Civil Engineering Research and Evaluation Laboratory, Technical Memorandum M-004, 20 May $195 \circ$, [ii], 13 leaves.[Mimeographed. Performance during field trials at Point Barrow for measuring thickness of ice over bodies of water.]

BRITISH COLUMBIA. DEPT. OF MINES AND Forests. WATER RIGHTS BRANCH. Summary of snow survey measurements in British Columbia, I935 to I952 inclusive. Victoria, B.C., Water Rights Branch, 1952. viii, 43 p. [Tabulated data
for nearly roo snow courses.]

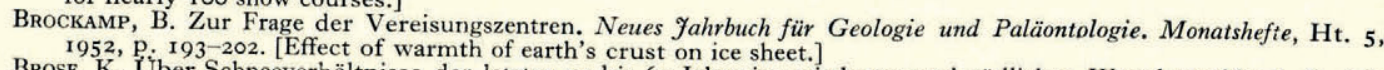

Brose, K. Úber Schneeverhältnisse der letzten 50 bis 60 Jahre im mittleren und südlichen Westdeutschland. Bericht des Deutschen Wetterdienstes in der U.S. Zone (Bad Kissingen), Nr. 38, 1952, p. 171 77 . Brown, P. R. Climatic fluctuation in the Greenland and Norwegian Seas [1900-49]. Quarterly Fournal of the Royal
Meteorological Society, Vol. 79, No. 340, 1953, p. 272-81. 
Browne, W. R. Pleistocene glaciation in the Kosciusko region. In GlaksSner, M. F., and RudD, E. A., eds. Sir Douglas Mawson anniversary volume. Adelaide, University of Adelaide, 1952, p. 25-4I.

BüPEL, JULIUS. Bericht über Klima-morphologische und Eiszeit-Forschungen in Nieder-Afrika auf Grund einer Forschungsreise $1950 / 51$. (Beiträge zur Geomorphologie der Klimazonen und Vorzeitklimate. 8.) Erdkunde, Bd. 6, Ht. $2 / 3,1952$, p. 104 - 32. [Height of snow line in Mediterranean region and glacial features in North African mountains during Pleistocene.]

Carter, George F. Radiocarbon dating. Geographical Review, Vol. 43, No 1. 1953, p. 121-24. [Summary of recent research.]

CASTEREt, Norbert. Probing ice caves of the Pyrenees. National Geographic Magazine, Vol. 103, No. 3, 1953, p. 391-

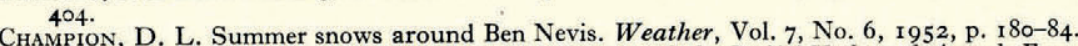

Cherrey, M. Glacier de Sarennes. Mémoires et Travaux de la Société Hydrotechnique de France, Vol. I, I950, p. 41-55.

Coloui, B. S., and MADEJSKI, M. E. Contribución al estudio del Glacier Torrecillas (Lago Menéndez, Chubut). Meteoros, (Buenos Aires) Añ. 2, Nos. 3-4, 1952, p. 209-14. [General observations; topography; glacier front.]

Conbel, J. Karsts et glaciers en Laponie. Revue de Géographie de Lyon, Vol. 27, No. 3, 1952, p. $257-67$.

COURT, ARNOLD. Antarctic atmospheric circulation. Compendium of Meteorology. Boston, Mass., American Meteorological Society, 195I, p. 917-4I. [Summary of present knowledge; bibliography.]

CRARY, A. P., and others. Preliminary report on scientific work on "Fletcher's Ice Island", T3. [By] A. P. Crary, R. D. Cotell, and T. F. Sexton. Arctic, Vol. 5, No. 4, 1952, p. 2 I 1-23.

Denny; C. S. Late Quaternary geology and frost phenomena along Alaska Highway, northern British Columbia and southeastern Yukon. Bulletin of the Geological Society of America, Vol. 63, No. 9, 1952, p. 883-922.

Dessens, Henri, and others. Nouvelles recherches sur les noyaux de condensation. [Par] Henri Dessens, C. Lafargue, et P. Stahl. Annales de Géophysique, Tom. 8, Fasc. I, 1952, p. 21-32. [Condensation nuclei examined by electron microscopy are hygroscopic, $\mathrm{NaCl}$ predominating.]

EBERs, EDith. Der Gletschergarten an der Deutschen Alpenstrasse. Forschungen zur Deutschen Landeskunde, Bd. 75, I 952,39 p., maps. [Glacier cliffs along the roadway in the Inzell valley of the Bavarian Alps.]

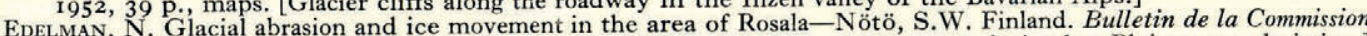
Géologique de Finlande, No. I 54, 195 I, p. $157-69$. [Chronology of ice movements during last Pleistocene glaciation.]

Einarsson, Trausti. Jökulfarg og landsig. Jö̈kull, Âr. 2, 1952, p. 25-26. [Depression of land in relation to glacier thickness. English summary.]

Emiliani, C., and Epstein, S. Temperature variations in the lower Pleistocene of southern California. Fournal of Geology, Vol. 61, No. 2, 1953, p. 171-81.

ERINC, SIRrI. Glacial evidences of the climatic variations in Turkey. Geografiska Annaler, Årg. 34, Ht. 1-2, 1952, p.89-98.

Evers, Wilhelm. Gletscherwinde am Nigardsbre (Südnorwegen). Ein Beitrag zur Landschaftskunde von Gletschertälern. In KAYSER, K., ed., Landschaft und Land, der Forschungsgegenstand der Geographie. Festschrift Erich Obst zum 65 Geburtstag. Remagen, Verlag des Amtes für Landeskunde, 1951, p. 123-36. [Local glacier wind in relation to weather conditions.]

Eytrónsson, Jón. Thykkt Vatnajökuls. J̈̈̈kull, Ár. I, r951, p. I-6. [Seismic soundings of Vatnajökull by the FrenchIcelandic Expedition, 195I.]

Eythórsson, Jón. Landid undir Vatnajökli. fökull, Ár. 2, 1952, p. 1-4. [Configuration of the Vatnajökull ice cap bed from the French seismic soundings. English summary.]

Eythórsson, Jón. Hafis vid Ísland. Fökull, Ar. 2, 1952, p. 31-32. [Polar ice at the coasts of Iceland. English summary.]

FANCK, ARNOLD. Werden und Vergehen eines Eisberges. Berge der Welt, Bd. 7, 1952, p. 43-57. [Considers the Greenland icebergs as products of one huge glacier and discusses their origin and end in relation to surrounding ocean

currents.]
FANCK, ARNOLD, and Heim, ALBERT. Blaublätter und Gletscherkorn. Berge der Welt, Bd. 7, 1952, p. 59-66. [Letter, and reply, written in I934. "Blue bands" in some West Greenland glaciers and in icebergs calved from them.]

FARRINGTON, A. The glacial drifts of Slieve Bernagh. Irish Geography, Vol. 2, No. 4, 1952, p. 153-55. [Suggests reconsideration of evidence provided by granite erratics.]

Finsterwalder, R. Die Gletscher der Bayerischen Alpen. Fahrbuch des Deutschen Alpenvereins, Jahrg. 1951, Überbrückungsband $1943-51,1951$, p. 60-66. [Bavarian glaciers.]

FinsterWALDER, R. Das Ergebnis der photogrammetrischen Gletschermessung seit 1885 in den Ostalpen. Allgemeine Vermessungsnachrichten (Berlin), I952, Nr. 3, p. 66-69. [Photogrammetric surveys in the eastern Alps since 1885.]

FLETCHER, JosEPH O. Three months on an Arctic ice island. National Geographic Magazine, Vol. 103, No. 4, 1953 , p. 489-504. [Includes useful photographs.]

Flint, R. F. The Ice Age in the North American Arctic. Arctic, Vol. 5, No. 3, 1952, p. 135-52.

Fristrup, Børge. Die Klimaänderungen in der Arktis und ihre Bedeutung besonders für Grönland. Erdkunde, Bd. 6 ,

Ht. 4, 1952, p. 201-12.
GARCIA-SÁINZ, L. L'origine des glaciers ibériques quaternaires et la trajectoire cyclonale de l'Atlantique. Comptes Rendus du Congrès International de Géographie, Lisbon, 1949. Tom. 2. Travaux des Sections 2 et 3. Lisbon, 1950, p. 722-30. [Two types of Quaternary Iberian glacier, the subtropical in most parts of the peninsula, and the alpine in the Pyrenees.]

[Glacier OBSERvations.] Relazione delle campagne glaciologiche r951. Bollettino del Comitato Glaciologico Italiano, 2 Ser., No. 3, 1952, p. 101-94. [Contributions on observations of the condition of 77 glaciers in the western, central and eastern Alps and the Apennines by 20 authors.]

[GLACIOLOGICAL EQUIPMENT.] Final report on development of ice mechanics test kit for Hydrographic Office, U.S. Navy; prepared by Soils, Foundation and Frost Effects Laboratory, Corps of Engineers, U.S. Army, New England Division, Boston, Mass. for Office of the Chief of Engineers, Airfields Branch, Engineering Division, Military Construction. Boston, United States Army, Corps of Engineers 1950 . [x, 127 p.]

Gresswell, R. K. The glacial geomorphology of the south-eastern part of the Lake District: Liverpool छ Manchester Geological Fournal, Vol. I, Part I, 1951, p. 57-70.

Gygax, F. Niederschlag und Abfluss im Einzugsgebiet der Magliasina, zum Wasserhaushalt des schweizer Hochgebirges. Beiträge zur Geologie der Schweiz. Geotechnische Serie. Hydrologie, Lief. 3, 1948, 100 p. [Run-off in connection with the water economy of the Swiss highlands.]

HAEFELI, R. Neuere Entwicklungstendenzen und Probleme des Lawinenverbaus im Anbruchgebiet. Zeitschriften des

Schrveizerischen Forstvereins, Beiheft Nr. 26. 1951, 29 p.
HARDy, C. T., and Muessig, S. Glaciation and drainage changes in Fish Lake Plateau, Utah. Bulletin of the Geological Society of America, Vol. 63, No. 11 , 1952, p. $1109-16$.

HARE, F. KENNETH. The present-day snowfall of Labrador-Ungava. American Fournal of Science, Vol. 249, No. 9, 1951, p. $654-70$. [Snow distribution maps of area where the Wisconsin-Laurentide ice sheet is believed to have originated.] 
HAWKE, E. L. Midsummer snow on Braeriach. Weather, Vol. 8, No. 4, 1953, p. I21. [Cairngorm Mountains.]

Hempel, L. Abtragung durch Schneekorrasion. Petermanns Geographische Mitteilungen, Jahrg. 96, 3 Quartalsheft, 1952, p. 183-84. [Snow erosion (nivation).]

Herdman, H. F. P. The voyage of Discovery II, 1950-5 I. Geographical Fournal, Vol. 118, Part 4, 1952, p. 429-42. [Southern Ocean. Discussion, p. 44I-42.]

HoINKEs, H., and UNTERstriner, N. Wärmeumsatz und Ablation auf Alpengletschern. I. Vernagtferner (Ötztaler Alpen), August 1950. Geografiska Annaler, Årg. 34, Ht. 1-2, 1952, p. 99-1 58. [Heat exchange and ablation on the Vernagtgletscher. Hollin, John. Oxford and Cambridge Expedition to North East Land, 1951 . Notes on equipment and methods.
Oxford University Exploration Club Bulletin, No. 5, 1952, p. 14-19.

Holmes, Chauncey D. Drift dispersion in west-central New York. Bulletin of the Geological Society of America, Vol. 63 , 1952, p. 993-1010.

Holmsen, P. Notes on the ice-shed and ice-transport in eastern Norway. Norsk Geologisk Tidsskrift, Bd. 29, 1951, p. 159-67. [Position of ice-sheds in last, and perhaps earlier, glaciations.]

HoPPE, GUNNAR. Hummocky moraine regions with special reference to the interior of Norrbotten. Geografiska Annaler, Årg. 34, Ht. $1-2$, 1952, p. $1-72$. Hough, JACK L. Pleistocene climatic record in a Pacific Ocean core sample. Fournal of Geology, Vol. 61, No. 3, 1953,
p. 252-62.

Ives, Ronald L. Glaciations in Little Cottonwood Canyon, Utah. Scientific Monthly, Vol. 7.1, No. 2, 1950, p. 105-17

Ives, Ronald L. Later Pleistocene glaciation in the Silver Lake Valley. Colorado. Geographical Review, Vol. 43, No. 2, 1953, p. $229-52$.

Ives, Ronald L. Anomalous glacial deposits in the Colorado Front Range area, Colorado. Transactions. American Geophysical Union, Vol. 34, No. 2, 1953, p. 220-26.

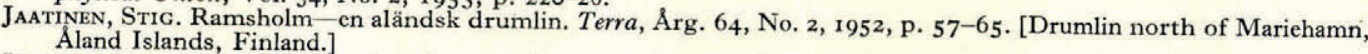

JAHN, ALFRED. Zjawiska krioturbacyjne wspólczesnej i plejstoceńskiej strefy peryglacjalnej. Acta Geologica Polonica, Vol. 2, No. I/2, I95I, p. I59-290. [Cryoturbation phenomena of the contemporary, and of the Pleistocene, periglacial zone; English summary and captions.]

KAMPE, H. J. Feuchtigkeitsverhältnisse in Cirruswolken und die daraus resultierenden Formen der Eiskristalle. Bericht des Deutschen Wetterdienstes in der U.S. Zone (Bad Kissingen), Nr. 38, 1952, p. 298-302.

KASSER, P., and HAEFELI, R. Glaziologische Beobachtungen am Grossen Aletschgletscher. Schweizerische Bauzeitung, Jahrg. 70, No. 35,1952 , p. $504-06$

KLEBELSBERG, R. vON. Die Gletscher der österreichischen Alpen $1951 / 52$. Mitteilungen des Österreichischen Alpenvereins, Bd. 78 , Ht. $1 / 2,1953$, p. $4^{-6 .}$

Kolumbe, E. Nachweis einer Wärmezeit zwischen Alt- und Mittel-Riss in Niedersachsen. Mitteilungen aus dem Geologischen Staatsinstitut in Hamburg, Ht. 22, 1953, p. 22-27. [Amelioration during Riss glaciation.]

KüPPER, H. Eiszeitspuren im Gebiet von Wien. Sitzungsberichte der Österreichischen Akademie der Wissenschaften. Mathematische-naturwissenschaftliche Klasse, Abt. 1, Bd. 159, Ht. 6-10, 1950, p. 199-206. [Certain glacial blocks in relation to sinking of the level of erosion.

Kulp, J. L., and others. Lamont natural radiocarbon measurements. x. [By] J. L. Kulp, W. Freely, and L. E. Tryon. Science, Vol. 1 1 4, 1951, p. 565-68.

Lagrula, J. Sur l'eustatisme. Comptes Rendus Hebdomadaires des Séances de l'Académie des Sciences (Paris), Tom. 234, No. 25, $195^{2}$, p. 2476-78. [Deals mathematically with the volume of continental ice in relation to the level of
the ocean.]

LANGMUIR, I. Project Cirrus. Final report. Part 2. Analysis of the effects of periodic seeding of the atmosphere with silver iodide. Schenectady, N.Y., General Electric Research Laboratory, 1953. 336 p. [Includes section on ice crystals. For Part $\mathrm{x}$ of this report, see below, under SCHAFFER, VINCENT J.]

LiBBy, Willard F. Radiocarbon dates. 2. Science, Vol. 114, I95I, p. 291-96. [Results suggest that Cary substage is more than 17,000 years old and that end of glacial period dates back ir 1,000 years.

LiotaRD, ANDRÉ-FrANK. L'expédition polaire française en Terre Adélie. Compte Rendu des Séances. Communications. Académie des Sciences Coloniales, Séance du 7 décembre 1951, p. 475-79.

LOUgEe, R. J., and VAN DER PYL, A. W. Glacial water levels in the Thames-Willimantic river valley. Scientific Monthly, Vol. 73, No. 5, 1951, p. 275-83. [Connecticut.] Ludlam, F. H. The production of showers by the growth of ice particles. Quarterly fournal of the Royal Meteorological
Society, Vol. 73 , No. $33^{8}, 1952$, p. $543-53$.

MAarlevElD, G. C. De asymmetrie van de kleine dalen op het noordelijk halfrond. Tijdschrift van het Koninklijk Nederlandsch Aardrijkskundig Genootschap, Deel 68, No. 3, 1951, p. 297-312. [Asymmetry of small valleys of northern hemisphere attributed to solifluction in areas not covered by ice-sheet.]

MAcClintock, PAUL. Crescentic crack, crescentic gouge, friction crack, and glacier movement. Fournal of Geology, Vol. 61, No. 2, 1953, p. 186. [Laboratory tests to show "crescentic gouge" i.e. glacial scoring with horns pointing
upstream.]

MACGREGoR, A. G. Metamorphism in the Moine nappe of northern Scotland. Transactions of the Edinburgh Geological Society, Vol. 15, Parts $1-2,1952$, p. 241-57. [Analogies with ice.] Manlex, Gordon. John Dalton's snowdrift. Weather, Vol. 7, No. 7, 1952, p. 210-12. [Instances of snowdrifts persisting
until late summer in English Lake District and northern Pennines.]

Manley, Gordon. Climatic variation. Quarterly fournal of the Royal Meteorological Society, Vol. 79, No. 340, 1953, p. 185-209. (Reviews of modern meteorology -9.)

Mason, B. J., and Owston, P. G. Ice crystals of spiral form grown from the vapour. Philosophical Magazine, Series 7 , Vol. 43, No. 343, 1952, p. $911-12$. [Unusual ice crystals growing on cooling pipes of cold store.]

McGerrigle, H. W. Pleistocene glaciation of Gaspé Peninsula. Transactions of the Royal Society of Canada, Third Series, Vol. 46, Section 4, 1952, p. 37-51.

MILlER, David H. Insolation and snow melt in the Sierra Nevada. Bulletin of the American Meteorological Society, Vol. 31, No. 8, r950, p. 295-99. [Observations made at Central Sierra Snow Laboratory, 1945-46.] MilleR, DoN J. Late Cenozoic marine glacial sediments and marine terraces of Middleton Island, Alaska. Fournal of
Geology, Vol. 61, No. 1, I953, p. I 7-40.

Montgomery, Margaret R. Further notes on ice islands in the Canadian Arctic. Arctic, Vol. 5, No. 3, 1952, p. 183-87. [Observations resulting from study of air photographs; 2 unexplained land-ice features of Ellesmere Island.]

Morandini, G. Relazione sugli studi di densità e temperatura del manto nevoso a cura della Commissione per le neve del Comitato Glaciologico Italiano. Bollettino del Comitato Glaciologico Italiano, 2 Ser., No. 3, 1952, p. 77-89. 
Morawetz, Sifghard. Periglaziale Erscheinungen auf der Koralpe (Steirisches Randgebirge). Mitteilungen der Geographischen Gesellschaft Wien, Bd. $94, \mathrm{Ht} .5 / 8$, 1952, p. 252-57. [Intense solifluction in this area to-day.]

MoRAWETz, SIRGHARD. Klimabeziehungen des Gletscherverhaltens in den Ostalpen. Zeitschrift für Gletscherkunde und Glazialgeologie, Bd. 2, Ht. I, 1952, p. 100-05. [Climatological record since 1887.]

Mortensen, H. Heutiger Firnrückgang und Eiszeitklima. Erdkunde, Bd. 6, Ht. 2/3, 1952, p. 145-60. [Main disclosure is a temperature inversion at $2,500 \mathrm{~m}$. over the Alps during Würm glaciation.]

Munk, W., and Revelle, R. Sea level and the rotation of the Earth. American Fournal of Science, Vol. 250, No. 11,1952 ,

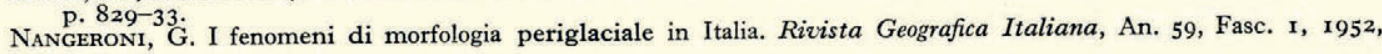
p. $\mathrm{I}-\mathrm{I} 5$.

Obenland, E. Über den Schneeanteil am Niederschlag. Bericht des Deutschen Wetterdienstes in der U.S. Zone (Bad

Kissingen), Nr. 38, 1952, p. 167-71.
Odum, Howard T. The Carolina bays and a Pleistocene weather map. American fournal of Science, Vol. 250, No. 4, 1952, p. $263-70$.

Orvig, Svenn. Floating ice islands in the Arctic Ocean. Geographical Revierv, Vol. 43, No. 2, 1953, p. 277-79.

PALLISTER, J. W. Some glacial features in the neighbourhood of Ecclefechan, Dumfriesshire. Transactions of the Edinburgh Geological Society, Vol. 14, Part 3, 1952, p. 389-95.

PAterson, T. T. Physiographic studies in north west Greenland. 1. Processes of denudation; 2. Island topography; 3. The geomorphological history of north west Greenland; 4. A nivation theory of cirque formation. Meddelelser om Gronland, Bd. 151 , Nr. 4, 1951, 60 p.

Pearce, D. C. A bibliography on snow and ice. Canada. National Research Council. Division of Building Research. Bibliography No. I, 195 I, 69 p. [Articles published in Canadian journals up to December 1950.]

Pike, KATHLEEN, and Godwin, HAROLD. The Interglacial at Clacton-on-Sea, Essex. Quarterly Fournal of the Geological Society of London, Vol. ro8, Part 3, No. 431, 1953, p. 261-72. [Suggests Clacton deposits belong to Míndel-Riss interglacial.]

PRYDE, J. A., and Jones, G. O. Properties of vitreous water. Nature, Vol. 170, No. 4330, 1952, p. $685-88$.

Pugh, H. LL. D. Snow fences. Great Britain. Department of Scientific and Industrial Research. Road Research Laboratory. Road Research Technical Paper No. 19, 1950, viii, 52 p. [Summary of information reference to research in U.S.A, Germany and Scandinavia.]

Quervain, M. DE, and others. Die Lawinenkatastrophen in den Schweizer Alpen, Januar und Februar 195x, ven M. de Quervain, T. Zingg, A. Roch und M. Schild. Die Erde, Bd. 4, 1952, p. 15-32. [Avalanches in Swiss Alps, 1951 .]

Ransley, T. J. Glacier studies in the Umanak district, West Greenland, 1950. Meddelelser om Gronland, Bd. I36, Nr. 2, 1952, [third article] $17 \mathrm{p}$.

RAU, WALTER. Über die Wirkungsweise der Gefrierkerne im unterkühlten Wasser. Zeitschrift für Naturforschung (Wiesbaden), Bd. 5a, Ht. 12, 1950, p. 667-75.

RAU WALTER. Eiskeimbildung durch dielektrische Polarisation. Zeitschrift für Naturforschung (Wiesbaden), Bd. 6a, Ht. II, I95 I, p. 649-57.

Robin, G. DE Q. Measurements of ice thickness in Dronning Maud Land, Antarctica. Nature, Vol. 171, No. 4341, I 953 , p. $55^{-5} 8$.

RobIN, G. DE Q. The flow and thickness of glaciers. Polar Record, Vol. 6, No. 45, 1953, p. 681-82.

RobIN, G. DE Q. The flow and thickness of glaciers. Polar Record, Vol. 6 , No. 45,1953 , p. $681-82$. I-2, 195 I, p. 10-16. [Relationship of air temperature to ablation of Jostedalsbreen, 1900-50.]

Rowell, A. J., and TURNER, J. S. Corrie-glaciation in the upper Eden valley, Westmorland. Liverpool E Manchester Geological fournal, Vol. x, Part 2, 1953, p. 200-07.

Ruhe, Robert V. Topographic discontinuities of the Des Moines lobe. American fournal of Science, Vol. 250, No. 1 , I952, p. 46-56. [Morainic complexes in Iowa and Minnesota.]

SAUBERER, F., and Dirmhirn, I. Der Strahlungshaushalt horizontaler Gletscherflächen auf dem honen Sonnblick. Geografiska Annaler, Årg. 34, Ht. 3-4, 1952, p. 261-90. [Radiation regime on horizontal glacier surfaces.]

Sc Geogration Bd. 27, [for] 1948, [pub.] 1950/51, p. 101-13. [Problems of Pleistocene erosion and deposition in the German fore-Alps.]

SchaEfer, VInCENT J. The formation of ice crystals in ordinary and nuclei-free air. (Project Cirrus.) General Electric Research Laboratory (Schenectady, N.Y.). Occasional Report, No. 33, 1952, 13 p. (RL 655.)

SchaEfer, Vincent J. Project Cirrus. Final report. Part i. Laboratory, field, and flight experiments. Schenectady, N.Y., General Electric Research Laboratory, 1953, 170 p. [Includes section on ice crystals. For Part 2 of this report, see above, under LANGMUIR, I.]

Schamp, H. Das Hochgebirges des südlichen Sinai und die Frage nach seiner diluvialen Vereisung. Die Erde, 1951-52,

Ht.r, p. 18-25. [Question of Pleistocene glaciation.]
SHARP, RoBert P. Shorelines of the glacial Great Lakes in Cook County, Minnesota. American fournal of Science, Vol. 251, No. 2, 1953, p. 109-39.

SIBINA G. L. SMIT. Interference of glacial eustasy with crustal movements and rhythmic sedimentation in Java and Sumatra. Geologie en Mijnbouw, N.S., 14 e Jaarg., No. 6, 1952, p. 220-25.

Sigurgeirsson, T. Kristalgerd íssins. Fökull, Âr. 2, I952, p. 26-28. [Crystal structure of ice.]

SIGURGerrsson, T. Kristalgerd issinterglacial deposit at Ipswich. Nature, Vol. I71, No. 4352, 1953, p. 578.

SPENCER, H. E. P. A Riss-Würm interglacial deposit at lpswich. Nätur berälning av glacialerosionen. Svensk Geografisk Arsbok, Årg. 27, 195 I, p. 134-46. [Thickness of granite sheets used for estimating ice erosion.]

Arsbok, Arg. 27, 1951, p. 134-46. [im Ruwenzorigebirge. Allgemeine Vermessungsnachrichten, 1952, Nr. 6, p. 142-47.

SugGate, R. P. Franz Josef Glacier, March 1951. New Zealand Yournal of Science and Technology, Sec. B, Vol. 33, No. 4, I952, p. 299-304. [Correlation between fluctuation and precipitation.]

W at major cities in the United States. Transactions. American Geophysical Union, Vol. 33, No. 6, 1952, p. $871-80$.

WoLFE, PETER E. Periglacial frost-thaw basins in New Jersey. Fournal of Geology, Vol. 61, No. 2, 1953, p. 133-41.

Wolfe, PETER E. Periglacial frost-thaw basins in New Jersey. Fournal of Geology, Wol. des Deutschen Geographentages, Bd. 27, [for] 1948, [pub.] r950/51, p. I 14-19. [Maintains that terrestrial factors in conjunction with Earth-orbit changes suffice to cause Ice Ages.]

E R RATUM

In the penultimate line on page $\mathrm{I}_{5}$ of the previous issue (No. $\mathrm{I}_{3}$ ) for " lat. $50^{\circ} \mathrm{I}_{5}$ ' S." read "lat. $59^{\circ}$ I $5^{\prime}$ S." MADE AND PRINTED IN GREAT BRITAIN BY WILLIAM CLOWES AND SONS, LIMITED, LONDON AND BECCLES 